\title{
The social procurement practices of tier-one construction contractors in Australia
}

\begin{abstract}
Social procurement is becoming an increasingly important requirement in the delivery of private and public- sector construction projects in many parts of the world, yet there is relatively little research in this area. Mobilising Furneaux and Barraket's (2014) social procurement typology, semi-structured interviews were conducted with senior managers from eight tier-one contractors in the Australian construction industry to explore and classify the types of social procurement strategies used in projects, the types of social value created and the barriers to implementation. Documentary data was also collected in the form of company policies and contract requirements. The results demonstrate the conceptual merit of Furneaux and Barraket's (2014) typology in a construction industry context by highlighting the different constraints on social value creation for each type of social procurement. The results also indicate that approaches to social procurement in the Australian construction industry are generally driven by a philosophy of risk mitigation rather than opportunity maximisation, are confined to low value and low risk construction activities and are constrained by a lack of existing and new supply chain social-value creation capacity. Construction industry social value chains are fragile in Australia and it is concluded that that in building the sector's significant untapped capacity to deliver social value to the communities in which it builds, priority should be given to three main strategies: third sector capacity building; barrier-to-entry reduction; and skills development in managing new cross-sector collaborations between public, private and third sector organisations.
\end{abstract}

Keywords: community; corporate social responsibility; social procurement; social value; social enterprise; third sector.

\section{Introduction}

Social procurement is becoming an increasingly important aspect of project delivery in the construction industry around the world as governments and socially responsible private clients seek to place new requirements on construction firms to demonstrate how their projects will leave a positive legacy in the communities in which they are built (Farag et al 2016, Burke and King 2016, Petersen and Kadefors 2016, Barraket and Loosemore 2017). Many of these requirements are enshrined in laws and regulations such as the UK's Social Value (Public Services) Act 2012, EU public procurement directives (European Union 2014), the US Public Law 95-507 Act of 1978, the Canadian Procurement Strategy for Aboriginal Business (2016), South Africa's Preferential Procurement Policy Framework Act (2000) and Preferential Procurement Regulations (2017) and Australia's Indigenous Procurement Policy (2015). Outside of the law, many private construction clients are also developing their own voluntary social procurement policies in a response to growing corporate social responsibility expectations from employees, the public at large and institutional investors for firms to behave like good corporate citizens (Loosemore and Higgon 2015). 
While there remains a lack of conceptual clarity around the emerging construct of social procurement within and outside the field of construction (Furneaux and Barraket 2014, Farag and McDermott 2015) social procurement is broadly defined as "the acquisition of a range of assets and services, with the aim of intentionally creating social outcomes (both directly and indirectly)" (Furneaux and Barraket, 2014: 269). In the construction industry, which often represents the focus of emerging social procurement policies, 'direct' social procurement involves purchasing construction products and services directly from socially responsible businesses and social benefit organisations which trade for a social purpose. Social benefit organisations are highly varied, cross multiple sectors and include social enterprises, Indigenous businesses, disability enterprises, minority owned enterprises, enterprising not for profits/charities, social businesses, cooperatives, enterprising charities and local businesses. In contrast, 'indirect' social procurement involves project managers requiring business partners in existing supply chains to do the same, through numerous mechanisms such as social clauses in employment contracts; supplier codes of practice; responsible sourcing policies. Through social procurement initiatives, project managers effectively create a quasi-market for certain types of social purpose business from multiple sectors (private, not for profit, community, social enterprise, charity), diversifying their project supply chains with the dual goal of maximising both economic and social value for their shareholders, stakeholders and clients (Furneaux and Barraket 2014). considerable confusion around what social value means in the industry due to a lack of guidance on how to deliver and define social value and a lack of prominence given to social value in public sector construction tenders. This social value can take many forms depending on the types of organisations involved. For example, some collaborations may be targeted at employing local businesses while others may be aimed at providing employment and training opportunities to disadvantaged groups such as the longterm unemployed, disengaged youth, $\mathrm{x}$-offenders, disabled people or Indigenous groups in countries with large indigenous populations such as Australia, South Africa and Canada. These initiatives can in-turn translate to numerous immediate, intermediate and long-term social impacts for families, local communities and society at large, such as improved income, health and well-being and reduced crime, substance abuse and incarceration. These social impacts can then be measured and monetised using a variety of emerging and controversial techniques such as cost benefit analysis and social return on investment (SROI) (Fujiwara 2013, Arvidson et al 2013, Haksi-Leventhal 2013, Maier et al 2015).

The dearth of construction management research in the area of social procurement is surprising given that the construction and engineering industry is seen as a major focus for the implementation of such policies due to its size, labour intensity, social and environmental impact and multiplier affect into the wider community (Loosemore and Higgon 2015). In particular, there has been no research into the range of social procurement initiatives which can be used to create social value in the construction industry and the barriers to social value creation which may exist. By mobilizing emerging typologies of social procurement outside construction, this paper seeks to address this important gap in knowledge by differentiating between different types of social procurement currently used in the construction industry. It will also address calls by Furneaux and Barraket (2014) for more insights into how different types of social procurement might deliver different social value outcomes in different circumstances. It will do this by addressing the following research questions: 
1. What are the types of social procurement strategies employed by tier-one contractors in the construction industry?

2. What are the types of social value being created?

3. What are the barriers to social procurement which currently exist?

Conceptually and practically, this research is important in testing the applicability to construction of general social procurement typologies being developed in other fields, thereby adding descriptive or interpretive validity to Furneaux and Barraket's (2014) typology by showing that it holds across different industry contexts (Maxwell 1992). As Burke and King (2016) show, while a small number of construction firms are developing capabilities to articulate and deliver social value, there is a general lack of guidance given to project managers in meeting these new requirements. While initiatives such as The Considerate Contractors Scheme the and the recently released National Themes, Outcomes and Measures (TOMs) Framework published by The National Social Value Taskforce (2018) provide a clear definition of social value which will eventually be adapted to construction, these are focussed on measurement of social impact, and there has been no research, grounded in empirical research to help construction managers conceptualise strategies to create social impact in their businesses and projects. Such research will help to address the conceptual lack of clarity which currently exists around the construct and help to clarify the new types of skills, roles, networks, organisations and relationships which according to Petersen and Kadefors (2016) are not well understood.

\section{Types of social procurement}

In seeking to bring some construct clarity to the social procurement debate, a number of conceptual frameworks have been developed in the emerging field of social procurement. For example, based on case study research Burkett (2010) and Newman and Burkett (2012) indicated that social procurement has four key dimensions:

1. A contract focus - use of social clauses in contracts;

2. A supplier focus - engaging directly with existing social benefit organisations;

3. A market development focus - developing the social enterprise sector;

4. A policy focus - developing and implementing social procurement policies.

At an operational level, Barraket et al (2012) proposed a typology which described three main ways to engage with social enterprises through social procurement:

1. Indirect subcontracting - encouraging suppliers as a condition of a tender or in contract negotiations to subcontract part of their work to social enterprises;

2. Direct contracting - contracting directly with social enterprises;

3. Purchasing agreements, joint ventures and Memorandums of understanding with social benefit organisations.

Most recently and building on this earlier work, Furneaux and Barraket (2014) proposed a more refined model which described four types of social procurement strategy based on four existing empirical cases. 
1. Type 1 - 'Direct' procurement of pure (non-construction related) 'social services' from non-profit organisations such as charities and community organisations.

Pure 'social services' (which have nothing to do with construction) such as health and education which are acquired 'directly' from non-profit organisations such as pure charities. One of the few documented examples of this in construction is Bridgeman et al's $(2015,2016)$ description of the Budding Brunels program delivered for organisations like Crossrail by the Construction Youth Trust (a non-profit organisation in the UK), although there are many examples of Type-1 social procurement in the public sector social procurement literature (Burkett 2010).

2. Type 2 - 'Indirect' procurement of 'social outcomes' from private sector with social outcomes embedded as secondary outcomes in construction products and services contracts.

A product or service is procured with additional social outcomes embedded into the contract and tender selection process so that they are produced 'indirectly' as a result of the purchase. For example, there may be a contract clause to require subcontractors to employ a certain number of apprenticeships or disadvantaged people such as ethnic minorities, refugees, indigenous, disabled or local businesses. This differs from Type 1 social procurement in a number of important ways. First, social services are normally incidental to the main purchase (although they can be made core to the contract) but are required as part of the purchase contract through contract clauses. Second, social services are provided by a private sector profit-making business (although they may ultimately subcontract to a not-for-profit). There are very few references to this type of social procurement in the construction management research literature, although there are a multitude of examples elsewhere which often involve the construction industry (Queensland Government, 2004, Toronto City Planning 2010, Halloran 2015).

3. Type 3 - 'Direct' procurement of 'construction products and services' from social benefit organisations (social enterprises, Disability Organisations, Indigenous Businesses, Cooperatives, Minority Businesses) which combine social and outcomes with construction-related products and services.

Goods and services are directly purchased from social benefit businesses via normal tendering, set aside, preferential tendering or joint ventures. Unlike Type 1, the type of service being delivered is not a social service but a construction product or service. However unlike type 2, the company delivering the service is a social benefit organisation which is driven by a social rather than commercial mission, as in traditional construction suppliers and subcontractors. There are very few examples of this in construction literature, although Loosemore and Higgon (2015) provide some case studies which involve the engagement of social enterprises in the UK construction supply chain and Denny-Smith and Loosemore (2017) explore the barriers to the employment of indigenous businesses in the Australian construction industry. 
4. Type 4 - 'Corporate Social Responsibility' management of supply chains to ensure they do no harm through employment of private sector socially responsible businesses.

Social outcomes are procured through existing supply chains as in Type 2. However rather than using contractual tools, the basis of procuring social outcomes here relies on soft instruments which provide independent verification that the business is socially responsible. These instruments include: ethical supply chain management; responsible sourcing; supply chain codes of practice; responsible supplier directories; ISO 20400:2017 Sustainable Procurement; certification schemes such as Considerate Constructors UK and capacity building and education initiatives such as the Supply Chain Sustainability School (Allen 2014, Glass 2011, Glass et al. 2012).

The social procurement literature suggests that construction firms which engage in social procurement can derive significant benefits beyond simply complying with emerging social procurement legislation and policies. These potential benefits include: competitive advantage and greater innovation in bids (with socially responsible clients); improved employee recruitment, engagement and retention; improved community engagement and public relations; leverage into new business networks and markets; and more resilient and diversified supply chains (Loosemore 2015, 2016, Barraket et al., 2016, Flammer, 2015, Andayani and Atmini 2012).

The recent trend towards the use of social procurement as a social policy tool is controversial. While advocates of social procurement promote it as a powerful mechanism for creating social value, some commentators have raised concerns around threats to basic principles of public governance and procurement law which ensure competitive neutrality and transparency in public procurement practices. While Burkett (2010: 53) notes, "social procurement does not mean creating special preference for social benefit suppliers", Barraket and Weissman (2009: 4) found that social procurement policies, when poorly designed and implemented, can disadvantage existing suppliers and even lead to an "inefficient mix of production across the economy". For example, while many social benefit organisations are managed by passionate people, they often have little commercial experience and struggle to achieve financial viability (Villeneuve-Smith and Chung 2013). According to Loosemore (2016) and Denny-Smith and Loosemore (2016) this has led to scepticism of social procurement in the construction industry characterised by: a misunderstanding of what social benefit organisations do; perceptions that social benefit organisations are charities and deliver low quality services, more slowly and at a higher cost than traditional subcontractors; perceptions that social benefit organisations will always prioritise social goals over economic goals; perceptions that social benefit organisations can't handle large construction work packages; and perceptions that inefficiencies and un-competitiveness will result from making changes to traditional procurement practices such as set-aside, preferential treatment, social clauses and unbundling large trade packages to allow social benefit organisations to tender. For these reasons, many construction project managers see social procurement as an administrative burden imposed on them and a risk to their 
productivity, competitiveness and efficiency (Loosemore 2015, 2016, Bonwick and Daniels 2013).

In addition to the actual and perceived costs associated with social procurement, Esteves and Barclay (2011) found that poorly designed social procurement policies can lead to unintended negative social impacts and even encourage perverse market behaviour. This phenomenon has been noted in the Australian construction industry by Denny-Smith and Loosemore (2015) who warned of unscrupulous construction companies incorporating as scam Indigenous companies in order to access significant government social procurement budgets dedicated to encouraging Indigenous businesses participation and employment creation Esteves and Barclay (2011) also warn that community resentment and dissatisfaction can often result from tokenistic compliance with social procurement policies which result in firms providing only menial, short-term and unsustainable jobs to disadvantaged target groups to cynically comply with social procurement requirements. There can also be structural damage to local economies as social purpose organisations which become part of the construction sector's sector supply chain become overly dependent on what is a temporary business opportunity and left vulnerable to the 'normal' business cycle when a project ends. Perhaps more concerning is the current lack of empirical evidence that social benefit organizations are any better at delivering social value than normal subcontractors in construction supply chains. The answer to this critical question is made more complicated by a lack of agreement and discipline around the practice of assessing social value, which ensures that costs and benefits of engaging in social procurement cannot be reliably established (Burkett 2010, LePage 2014). Finally, in addition to these concerns around the opportunity costs and economic inefficiency of social procurement, there have also been long standing concerns around the legality of the process. For example, Arrowsmith and Kunzlik (2009) highlight a range of legal concerns such as overlaps with other policy areas like human rights, gender equality and environmental and energy policy, hindrances to free trade and even the provision of unlawful state aid. Burkett (2010: 52) claims that the "biggest obstacle to increasing and broadening the use of social procurement processes is the misperception that such approaches exist 'under the radar' or somehow contravene legislation or policies".

\section{Method}

To collect data about the different types of social procurement used in construction projects, the type of social value being created and the barriers to implementation, Furneaux and Barraket's (2014) typology of social procurement was mobilised as a conceptual framework. This framework was adopted because it represents the most recent typology available which has evolved as a gradual refinement of previous typologies such as Burkett (2010), Newman and Burkett (2012) and Barraket et al (2012), although there is no evidence that it has been empirically tested as yet. In order to test the framework in a construction context, data was collected using semistructured interviews with senior managers with responsibility for social procurement, from eight separate Tier-1 construction organisations in Australia. There are fifteen official Teir-1 contractors in Australia as represented by their peak body called the Australian Constructors Association and the contractors in our sample were purposefully selected from this membership list to provide a good cross-section of construction market areas (social and economic infrastructure, commercial and 
industrial and residential building). Tier-1 contractors were the unit of study based on research by Loosemore (2016) which shows that they are in the front-line of responding to new social procurement requirements and that contractors and subcontractors lower in the supply chain currently have little understanding of this area. To qualify for inclusion in the sample, the contractors had to be completing large scale construction projects and government work, since the literature has also identified that governments are currently the primary driving force behind social procurement in Australia.

Semi structured interviews were chosen to collect our data for a number of reasons: the conceptual lack of clarity around social procurement in construction and more broadly; the small number of tier-1 contractors in our population; and the lack of clarity in many of these organisations about who has responsibility for this new area (Petersen and Kadefors 2016). These constraints meant that surveys would have likely produced unreliable results since there was a high risk of a survey going to the wrong person or being misunderstood due to the newness of the subject matter and terminology. This has been identified by Punch (2013) and Nagy et al (2011) as a risk in any subject area which is new to the population being sampled. Furthermore, given the potential for social desirability bias in any CSR-type research (Loosemore and Phua 2011, Loosemore and Lim 2017), semi-structured interviews allowed the researchers to probe the respondents for further information if they needed to verify a response.

Our approach to sampling our interviewees was purposeful and involved a discussion with relevant people (usually starting with the Head of Procurement who was sent the interview questions in advance) until the single most knowledgeable person could be identified to answer the interview questions. The resultant sample is shown in Table 1.

\section{INSERT TABLE 1 HERE}

Table 1 Sample details

The purpose of the interviews was to explore:

1. The types of social procurement used by project managers (Type 1, 2, 3 or 4).

2. Project management objectives for using social procurement (commercial, reputational, client, economic/competitive advantage, social, environmental);

3. Types of social value created in projects (training and employment for disadvantaged jobseekers, stimulating the local economy, providing opportunities of social or educational inclusion of residents in large scale developments);

4. Types of social benefit organisations used in project supply chains (social enterprises and Indigenous businesses, disability enterprises, minority owned enterprises, enterprising not for profits, charities, social businesses, cooperatives, charities, local businesses);

5. Barriers to social procurement in projects (industry attitudes, cultures, large work packages, existing subcontractor relationships, resistance to change, competitiveness, social benefit organisational constraints) 
The interviews lasted between one and two hours and were conducted in the respondent's workplace. Where available, documentary data was also collected to verify the interview results and to provide more detail on company policies and contract social procurement requirements.

The open-ended interview questions were designed to collect narrative responses, contextualising the individual perspectives of each respondent, while allowing the expression of individual views. The interviews were recorded and transcribed and analysed using Reissman's (2008) approach which describes the key to producing a good narrative account as the use of open-ended questions which are broad enough to allow respondents to answer a question by following their own individual and 'instinctive' path through their experiences. Employing Reissman's (2008) approach to narrative analysis involved us analysing the thematic, structural and dialogic aspects of our interview data. The thematic analysis involved keeping the respondent stories intact and emphasising the words, phrases and themes used in the narrative over its structure, content and form. The structural analysis looked into the ways in which these narratives were structured, using a coding framework which focussed on the types of social procurement (types 1,2,3 and 4 as described above), objectives of social procurement (environmental, disabled, Indigenous, housing etc), social value created (training, employment etc), social benefit organisations involved (Indigenous businesses, social enterprises, community groups etc) and barriers to social procurement (supply chain capacity, experience of working with third sector organisations etc). Dialogic analysis focused on 'performed' accounts produced by our respondents, focussing on the roles and relationships formed during the social procurement process.

True to the tradition of narrative analysis our results are presented by using a combination of narratives and numbers because we wanted the results to retain the full richness of insight contained in the qualitative data we collected (Clandinin and Connelly 2000, Meisel and Karlawish 2011). Clearly, it is not possible to recount everything participants said in this paper. Instead we present the main themes emerging from the data using representative quotes and where relevant descriptive statistics from numerical counts of key themes which emerged in the data.

\section{Results and Discussion}

For clarity, in presenting our results around the types, motivations and barriers to social procurement in construction, we have organised them using Furneaux and Barraket's (2014) typology of social procurement strategies.

\section{Type 1 - Procurement of pure 'social services' directly from non-profit organisations}

$75 \%$ of the companies interviewed had engaged in some form of Type 1 social procurement by directly purchasing social services from a non-profit organisation.

For example, R2 had directly employed a range of charities and community organisations to work collaboratively with employment providers and the construction supply chain to try to innovate in the delivery of employment opportunities to people suffering disadvantage in the communities in which it built. Drug and alcohol 
programs, transportation assistance to help people get to work and workplace support and mentoring were some of the support services provided by the charities and community organisations involved. R5 and R6 had directly engaged a charity to implement an apprenticeship scheme on one of their projects. However, this also came with a number of challenges which reduced potential benefits to the construction companies involved and highlighted the need for adequate support structures to be put in place to support beneficiaries transitioning into work. Our findings indicated that these support structures are often missing when engaging with the third sector due to the resourcing constraints they face:

"We did engage kids in an apprenticeship scheme through [charity name]. But to be honest I would say that was more of a hindrance to us than a benefit. They required a lot of supervision. They weren't able to work autonomously.... I don't think they wanted to be there, probably more because someone had told them to be there. So yeah whilst that was us getting a perceived benefit through a social means it was really us providing work experience for those kids, more so than us receiving a benefit from their work". R3

"We'll take as many [indigenous graduates] as you've got that are going to fit the role. We'll have work for as many as they can give. But I don't want them to give us someone who is not aligned with our business and our culture". R5

"Most of the efforts have been tokenistic, which is as much about the lack of product and opportunity as anything else. The choices aren't there, there are very few providers". R1

These comments also highlight the commercial realities and motivations of working directly with not-for-profit organisations and supports the work of Porter and Kramer (2011) who argue for the importance of developing a shared-value proposition if such partnerships are to succeed. The results indicate that there are also clear costs and risks for construction firms of working with not-for-profits in integrating disadvantaged people with special needs into the construction workforce. The findings indicate that intermediate labour organisations set up by not-for-profits to generate income by providing disadvantaged labour to the construction industry, need to ensure that the people they provide are not only work ready but match the needs of employers and are supported by a backbone support infrastructure to support their transition to work. There is also an important need to educate employers about the challenges of employing workers who have suffered various forms of disadvantage.

The results also resonate with Barraket et al's (2016) observations around the challenges involved with the merging of different institutional logics in social procurement. Barraket et al (2016) note that organisations are constituted in and through social contexts which produce industry specific norms and assumptions and when these institutional logics compete there can be significant inertia for change in implementing social procurement. This is a challenge which Petersen and Kadefors (2016) also highlight in their research into construction social procurement in Sweden - arguing that this will result in new institutional configurations which are not yet understood. It is clear that if Type 1 social procurement is to work then not-for-profits set up as intermediate labour organisations which target the construction sector as a potential market need to adapt to the needs of the construction sector and seek to 
understand and reconcile the different institutional logics which lie at the heart of Type 1 social procurement success.

Other challenges were highlighted with Type 1 social procurement. For example, R5 was sceptical of working with charities to deliver social programmes because they have "difficulty reporting and measuring" their social impact. This is important because according to Burkett (2010: 48) "it is the management of the contract once it is awarded, and in particular how it is monitored and evaluated, that defines whether or not social procurement is worth all the effort". This concern also reflects recent research by Flatua et al (2016) and Seivwright et al (2016) who point to a lack of funding, standards, tools and practices for measuring and reporting social impact across the community sector. Pritchard et al's (2013) analysis of 1000 charities also highlights numerous barriers to impact measurement and as Harlock (2013) points out, while many good social impact reports, best practice guidelines and toolkits have been produced, there remains a lack of conceptual clarity about social impact measurement with very few robust, comprehensive and empirical studies to draw from. As the Productivity Commission (2010: 38) report into the contribution of the Australian not-for-profit sector noted, "Most measurement frameworks that seek to report at a sectoral level operate at only input or output level of contribution". This inturn means that it is difficult for supporters of social procurement to point to any reliable evidence that they are achieving the social value desired.

However, it is notable that one respondent had innovated to develop a potential solution to these problems by adapting the collective-impact model developed by Kania and Kramer (2011). Notwithstanding recent criticisms of this approach (Himmelan et al 2017), it was this contractor's ability to distil their cross-sector collaborative approach into five key features which could be implemented within the practical time and resource constraints of a construction project which seemed to secure a successful outcome for all stakeholders. These key features are listed below and represented the basis of 'Connectivity Centres ${ }^{\odot}$ ' created on a range of projects by this respondent which had successfully transitioned hundreds of disadvantaged people from a range of backgrounds back to sustainable employment across a range of projects over a period of about ten years

1. A shared understanding of the problem and a joint approach to solving it through agreed upon actions;

2. A consistent process for collecting data and measuring results across all the participants which ensured shared accountability;

3. A clear plan of action and coordination of mutually reinforcing activities for each stakeholder;

4. Open and regular communication between all key stakeholders;

5. A backbone organisation with dedicated staff to coordinate participating organisations and agencies.

As the respondent concerned stated:

"The Connectivity Centre concept originally arose from a practitioner's understanding of a major disconnect between the Commonwealth Government sponsored employment brokerage industry and employers in the Building industry. Fragmentation, an inward focus and the need for immediate results were, and remain common features of both industries. Each industry's 
ignorance of the other, often mitigated against good outcomes in placing jobseekers. A Connectivity Centre, by acting as a hub for collaboration and dialogue between providers, employers and community and Government agencies has been a successful solution. The "Collective Impact" concept that underpins a Connectivity Centre has delivered, not just in improving pathway and employment outcomes for disadvantaged jobseekers on major building projects, but also for other industries and the wider community in delivering social value. Collaboration, Innovation, Education and a common language, are the foundation on which both a Connectivity Centre is built and the delivery of community value relies" $\mathrm{R} 2$

Type 2 - Procurement of 'social outcomes' from private sector with social outcomes embedded in products and services contracts

Table 2 shows that only one organisation (R6) had not engaged in Type 2 social procurement and that all others had experienced the use of social clauses and criteria in their contracts - either being imposed on them $(\mathrm{N}=5)$ or by imposing them on their supply chain $(\mathrm{N}=5)$. Three respondents $(\mathrm{R} 2, \mathrm{R} 5, \mathrm{R} 7)$ had used back-to-back contract clauses (originating with their client's contract) to pass these risks onto their supply chain. The two developer respondents $(R 3, R 8)$ had done this voluntarily without being promoted by clients and two other respondents (R1, R4) had not leveraged their supply chain at all to respond to their client's social clauses meeting these requirements in-house.

\section{INSERT TABLE 2 HERE}

Table 2 Type 2 social procurement

The reason for this rather inconsistent picture appeared to be related to the low capacity of existing supply chains to deliver on social outcomes desired. This is problem highlighted by Barraket and Loosemore (2017) who concluded that there are significant differences in experience and opportunity for collaboration based on supply chain position and organisational scale and that these have notable effects on the co-creation of social value and the legitimacy of different social benefit providers in the construction industry. Finally, when social clauses were used, they were almost entirely targeted at subcontractors rather than consultants working in the construction supply chain. This represents a significant loss of potential leverage in Type 2 social procurement practice, although contractors have far less influence over consultants compared to developers with vertically integrated business models, which generally makes social procurement much easier to implement. As R5 stated:

"Yes, with the subcontractors but with the design consultants there's not the interest or motivation to include it within their professional services agreements. So that is an area that needs to be expanded".

The two respondents who had not had social value clauses passed down onto their contracts were both property developers, R3 and R8. However, as the client on their own projects they had voluntarily implemented social value clauses. 
"The clauses are across the board, [on one project we] asked for apprenticeships, volunteering to regenerate local bushland, educating and visiting the local school to talk about construction and the opportunities for people to come into the industry". R8

A number of respondents argued that the use of social clauses in contracts was the most effective way of achieving social outcomes but that the effectiveness of this approach was dependent on having people in the business who understand the requirements. As $\mathrm{R} 5$ stated:

"The fundamental thing to do, at the end of the day, is to insert it (social procurement) into the contracts. So we inserted social clauses into our subcontracts, which hadn't been done before.... The single most important thing to do is embed it in contracts [...] then have people within the organisation who understand [the requirements] and support that discussion".

"All of the indigenous and other government social requirements are embedded in their contracts [with subcontractors]. If there's a head contract requirement to do it, then we put it in the subcontract's. We go back to back with what we need to do. So certainly we will pass those onto everybody".

These results are consistent with the findings of Bonwick and Daniels (2014) who identified that most social procurement in Australia is being achieved through the use of contract clauses. Similarly, in the UK, the Cabinet Office's (2015) evaluation of the UK Social Value (Public Services) Act (2012) found that there had been "widespread use of social value in construction contracts". Our results also reflect general risk management literature in construction which shows that it is normal practice for any new risk transferred to a major contractor to be passed down the contractual chain to subcontractors and suppliers in the use of back-to-back contracts (Edwards and Bowen 2005). However, Loosemore's (2016) research into social procurement in construction sounds a note of caution with this strategy in that many existing subcontractors in the construction supply chain are ill-equipped to interact with the not-for-profit sector and to effectively manage the disadvantaged cohorts which they may find working on their projects. They typically require a lot of support to enable this strategy to work. Furthermore, the construction risk management literature also contains a warning, albeit in other contexts such as safety, that very often these small organisations in the supply chain are generally unaware and ill-equipped to deal with the risks they are being given (Smith et al 2014). So the construction industry's traditional risk transfer mentality, when applied to social responsibilities, raises many new challenges for the construction supply chain around building skills and capacity (and indeed, attitudes) towards accepting and delivering on these new requirements. Given the general unsophistication of the construction supply chain and the low margins they operate on, this new extra responsibility is unlikely to be accepted warmly. At the very least, there will need to be some phasing-in of these new responsibilities and subcontractors will need to be provided with significant education, training and ongoing support to understand and manage these new requirements.

As R5 noted:

"So one of the actual clauses - the subcontractor must ensure that $20 \%$ of their staff are apprentices. Now some trades might not have apprentices, like 
in piling works. But you need to have the requirements written into the contracts to start the conversation. Ok, you don't have apprentices, but what else can you do towards training young people?"

Figure 1 shows the results of the structural analysis relating to the social objectives each respondent described when discussing Type 2 social procurement. More than one objective could be recorded per respondent.

\section{INSERT FIGURE 1 HERE}

\section{Figure 1 Social Objectives of Type 2 Social Procurement}

The ability of Type 2 social procurement to achieve a wide variety of social objectives is consistent with the literature in this area. However, that the most common objective was Indigenous participation and training/up-skilling is a direct response to recent Federal and State social procurement directives in Australia which focus on these areas (Commonwealth Indigenous Procurement Policy, 2015; NSW Government Policy on Aboriginal Participation in Construction, 2015).

"[We try to] achieve the government initiatives that they set out, being indigenous and local workforce". R4

"[We have] a heavy indigenous focus at the moment. The focus is still very much on our accounts and what our clients require. As a Commonwealth Agreement there is an IPP (Indigenous Procurement Policy) Requirement, so we're heavily focussed on that because it's a contract requirement". R1

It is interesting that this focus contrasts with Cabinet Office's (2015) evaluation of the UK Social Value Act 2012, which points to its deliberately broad and non-prescriptive nature. In contrast, the Australian approach follows the US tradition of being more targeted towards specific disadvantaged cohort groups (particularly Indigenous people) and underpinned by quantitative targets which companies have to meet. While the advantage of the Australian approach is the targeting of certain priority disadvantaged groups, the advantage of the UK approach is the flexibility it provides to deal with a variety of social causes and disadvantaged cohorts which might change over time. The relative outcomes and institutional and structural consequences of both approaches are unclear and need to be researched to guide future policy in this area. For example, LePage (2014) found that the most successful social procurement initiatives in Canada were implemented by those who had a particular target cohort in mind and Burkett (2010: 62) recommended that "place-based social procurement can be highly effective, both from the perspective of social impact and procurement process" and emphasized the importance of "understanding the context" and not providing "generalized social benefits [which] are not likely to be effective from an impact perspective".

Finally, our findings in Type 2 social procurement support research which shows that as well as having well designed social clauses, it is critical to have people who understand and can communicate what social outcomes are required, why it is needed and how it will be monitored and enforced (Blee and Pidgeon 2014, 
Department of Trade and Industry 2006, Halloran 2016). This combination of contractual and interpersonal strategies is likely to be important in avoiding the compliance-based mentality which Burke and King (2015) found to be a characteristic of social procurement in the construction industry. It also supports Halloran (2015: 6) who states that to "focus on the legal and procurement processes tends to detract from the more important question of how to make social clauses work for the intended beneficiaries. Procurement teams assume this is easy, but where the requirements are inappropriate, it is significant, and failure - where the outputs are not achieved - can easily discredit the whole approach. What is needed is a systems approach where the legal and procurement issues are just one of several elements of a process that has to work in its entirety if the community benefits are to be achieved".

Type 3 Social Procurement - Procurement of construction products and services from social benefit organisations

Figure 2 shows the results of the structural analysis relating to types of social benefit organisations which our respondents had collaborated with.

\section{INSERT FIGURE 2 HERE}

Figure 2 Collaborations with social benefit organisations

It is not surprising given the imperatives around Indigenous Procurement discussed above that Indigenous businesses emerge as the joint leader in collaborating with the construction industry in our research. This was likely a response to the Australian Government's Indigenous Procurement Policy (2015) which requires construction firms tendering for public sector contracts to employ and train a certain percentage of Indigenous employees and businesses.

This is likely to differ in other countries as the social context of social procurement shifts in response to community needs and priorities. However, large numbers do not necessarily translate to meaningful collaboration and as R7 noted, there is often a challenge in finding Indigenous businesses of the required scale to use meaningfully in their supply chain, rather than relying on them for tokenistic purchases only:

'We've got a big interest in indigenous businesses, but what we find hard is finding services that we require that indigenous businesses can deliver. For example, if we're delivering a $\$ 250$ m shopping centre there's only a few companies in Australia that could deliver that and they by fact are not indigenous organisation. There are opportunities in lower values but we find it difficult to procure and instead try to partner with our contractors to leverage their buying value to deliver that". 
This supports the recent research by Barraket and Loosemore (2017) which argued that existing processes of social value co-creation through supply chain relationships more closely reflect a cooperative than a collaborative model, are largely driven by commercial concerns and influenced by industry norms and institutional imperatives. These findings also reflect insights into Indigenous construction businesses by Denny-Smith and Loosemore (2016) which found a significant number of barriers to entry which include: building scale and capability to compete with industry incumbents; adjusting to unique industry cultures and work practices; breaking into networks and building social capital; being undercut by competitors; low price driving most procurement decisions and a perceived lack of trust in the ability of Indigenous business to deliver work to the same standards as existing subcontractors.

While charities might not face the unique problems which Indigenous businesses might face integrating into construction, many are common. For example, R5 noted the lack of trust in the loyalty of these organisations:

“Charities haven't figured largely in this. What you tend to find is they're working for the benefits of their constituents, not necessarily their employers. They've placed kids into [names of large construction firms]., but not on the large scale of recruitment and training that we're talking about for these sites".

R5 and R6 also noted that it was challenging to involve social enterprises during construction due to the unknown risks and capabilities involved:

"You can partner with social enterprises but it's hard to do during construction. It is much easier in a retail space, so for example towards the back end of the project we had retail pop-ups. Social enterprises and charities are at the back end and not during construction".

“We don't necessarily work with a lot of organisations ....social enterprises and charities.... like that. There are a lot of obligations for organisations working on site or delivering materials to site, which on the face of it might seem quite simple but isn't that basic. For example, if there was a school of disabled adults around the corner of the job and you said come and work or paint. There might be simple tasks that on the surface seem safe enough for them to do. But everyone on site has to have workers compensation insurance. Everyone has to have a SWMS (Safe work method statement) and be inducted into the various safety policies. Say if they were involved in the manufacturing, those products need public liability insurance provided. If there were issues down the line with that product they are the ones that will be liable. I don't want to be suing a not for profit company in the future".

These findings support research by Keast and Mandell (2014) into cross-sector collaboration and social procurement outside construction, which found it to be a difficult aspiration to achieve in practice. This is because collaboration is based on the formation of stable long-term and high trust relationships characterised by high levels of reciprocal interdependency, open and frequent communication, shared risk and power, dense relationships, commonly recognised goals and a recognised need to collaborate for mutual success. Our results indicate that the relationships that are formed through Type 3 social procurement are more in-line with notions of 
'cooperation' and 'coordination' which sit at lower ends of the relational spectrum and involve shorter-term, more informal, temporary and largely involuntary low-trust relations between organisations driven by individual or semi-independent goals.

Figure 3 shows the results of the structural analysis relating to the social objectives each respondent described when discussing Type 3 social procurement. More than one objective could be recorded per respondent.

\section{INSERT FIGURE 3 HERE}

\section{Figure 3 Social Objective of Type 3 Social Procurement}

Again, the results heavily reflect the current Indigenous focus of the regulatory environment in Australia. They also illustrate the relatively low penetration of other types of social benefit organisations such as social enterprises into the construction sector.

As noted by respondents R6, R2 and R5, there are numerous barriers to entry for these organisations in accessing the construction industry and that engagement to date is often tokenistic:

"I would have very limited input on that to be honest. It's really not a big thing in our industry and I think it speaks to the high barriers for entry that we require such as insurances, resourcing, skills and experience, balance sheets. There are a lot of things that, when we are engaging a subcontractor we take into consideration".

"We have, but not to any great extent. Where we have it's been tokenistic. [...] We're not aware of those organisations providing a wider range of goods and services to the construction industry.

"During construction it is hard to find social enterprises that are relevant to construction, they could be providing workwear or catering for food, or involved in security. When I looked at this a few years ago there wasn't a lot in construction. Security was about the closest I got from a construction point of view, particularly on large scale construction projects".

Loosemore's $(2015,2016)$ research shows that the reasons for the lack of social enterprises in construction appear to be complex, deeply seated and numerous and relate to supply issues, the temporary and transitionary nature of construction project organisations, cosy supply chain relationships and clients which do not value social initiatives, established industry cultures, perceptions and procurement practices which prevent social benefit organisations tendering for construction work, the emerging and immature state of the Social Enterprise Sector and the high risk and highly regulated nature of construction work - particularly in areas like safety.

Both R3 and R8 discussed how they had needed to provide additional assistance to bring social enterprises up to their safety standards. So there are clearly costs and risks associated with this strategy. 
"A lot were simply job ready programs, or English as a second language. When you're onsite, a lot of people can't read or write well, or speak English well. If you have a safety culture, you have to make sure people understand what you're telling them to do".

There are also institutional implications - both formal and informal. As R5 insightfully noted, working effectively with social benefit organisations requires "a different way of thinking" and capacity-building initiatives which can help such organisations overcome the barriers identified above.

"[When engaging with a social enterprise] the organisation has got to be prepared to mentor that social enterprise and bring them along the journey. You need to partner, it's not a set and forget thing".

"For a Tier 1 contractor, it's quite a rigmarole to ensure all your safety and other related documentation is up to scratch. One lesson we learnt is that a lot of the local indigenous businesses didn't have the experience of working with a Tier 1 construction contractor, so we provide the opportunity of sitting down with those businesses and explaining what information was required. This allowed more indigenous businesses to provide goods and services on the project".

"[...] where needed to we help them manage the process to come in under our systems. We have systems that we abide by, certain measures and procedures we need to do. If a subcontractor needs assistance we don't bend the rules and lower our level of standard, but we assist them to get to our level of standard".

These findings in relation to Type 3 social procurement taken together, help to elaborate the concept of 'social value chains' recently proposed by Barraket et al (2016) as a new way to understand how organisations in industries like construction are collaborating with social benefit organisations to bring about social impact and how these organisations are also seeking to scale-up by working with bigger businesses. The concept of the 'social value chain' is an extension of Porter's (1985) value chain concept which described the set of organisations and activities that a firm operating in a specific industry performs in order to deliver a product or service to a market. However, in the social value chain, the focus is on the organisations and activities which deliver social value. In contrast to other industries, on which Barraket et al (2016) base their research, this research shows that these social value chains are not yet seen as a competitive advantage in construction and at the moment, are fragile and more dependent on the leverage of existing industry incumbents than social benefit organisations which need to overcome significant barriers to entry such as conflicting institutional norms, cultures, path dependencies, perceptions, attitudes and conflicting objectives.

Type 4 Social Procurement - Procurement of social outcomes through employment of private sector socially responsible businesses.

Our results indicate that one of the main problems for companies engaging with Type 4 social procurement is the lack of standards and certifications which can be used to reliably vet an organisation as socially responsible or not. R3 and R6 
discussed ISO Standards and various international indices such as Global Reporting Initiative (GRI) and Dow Jones Sustainability Index. However, they felt they were more about building quality and environment rather than achieving social requirements and that they were too onerous for the small businesses in their supply chain. To address this problem, five respondents had developed "supply chain schools" (R2, R3, R4, R5, R7) and two (R4, R7) were both members of the Australian Supply Chain Sustainability School - a collaborative government/business arrangement whereby major firms make sustainability resources available to their supply chains for free in an attempt to raise awareness and standards in sustainable practices, although again this is largely focussed on environmental rather than social issues. R7 noted the logic justifying the School:

"[The Supply Chain School] was leveraged off that model (from the UK) and brought to Australia through a number of founding partners who all saw the need to come together in a non-competitive sense to work together to educate our suppliers because there's probably an overlap of $60-80 \%$ of our suppliers".

R2, R3 and R5 each discussed their own training centres which were based on individual projects but the focus was on general skills training than on building supply chain capacity in the delivery of social value. As R5 pointed out, the aim of their inhouse school was to:

"Give the employees of the subcontractor an opportunity to grow their skills and enhance their employability, and capacity to earn through the [Construction School]".

In all, the results reflect the findings of Glass et al (2011, 2012), Murray et al (2011) and Upstill-Goddard et al (2012) who show that the construction industry is lagging behind other industries in its adoption of responsible sourcing strategies. These authors show that sustainable business concepts such as corporate social responsibility, responsible sourcing and considerate construction, while being experimented with by a few major firms who operate in the top tier of the industry remain a mystery to the vast majority.

\section{Drivers of Social Procurement}

Figure 4 shows the results of the structural analysis relating to the main drivers of social procurement for the sample. More than one category could be recorded per respondent.

\section{INSERT FIGURE 4 HERE}

Figure 4 Drivers of social procurement

These results show that regulatory factors are the main driver of social procurement in construction. However, upon further investigation it was clear that our respondents associated government regulatory imperatives around social procurement with 
commercial imperatives since government clients represented a large proportion of the work undertaken by the companies we interviewed. Outside of government construction projects in Australia, there are no regulations which create a requirement for major contractors to engage in social procurement activities, other than as a way of meeting laws relating to wider corporate social responsibility requirements. As the statement below shows, our research supports the findings of Akotia and Parneet (2017) who found that the most important driver of social sustainability in construction firms is reputation and competitive advantage.

"The things that motivate us are business related. If we want to win a job, and a social objective is a requirement of that then we'll do it. For us and probably a lot of other builders, it's less about being a good social citizen and more about how we support our growth, business and our bottom line. It sounds selfish, but it's the reality of our business. The indigenous example is in part us wanting to be good social citizens but also about preparing our business for government work as part of our business plan".

Private clients barely featured in the interviews with contractors, although the two major property developers had other internal drivers revolving around general corporate social responsibility strategies which were more reflective of the 'investment mindset' identified by Barraket and Weissman (2009). The integrated nature of their businesses which involved them designing, constructing and operating facilities also provided shared-value incentives to give back to the communities in which they were building. The influence of business models on social procurement motivations would be an interesting avenue for future research.

"We go into a community and put a once in a generation project into that community. We're looking to create positive impact in that community - we're not looking to get in, churn the community, burn it and leave. We're often an asset operator so we want to provide them with an asset that enhances the community, an asset that is embedded and embraced by the community - that is a big driver. That is also a throughput for a commercial opportunity - our brand is enhanced in that regard and if we can enhance it so people want to move into our houses, shop in our shopping centres, live in our retirement villages then that is a big plus for us as a brand". R3

"This is my personal belief and understanding, but [we] are motivated to doing good for the community first and foremost. We do acknowledge that we are proud of the good work that we do. That might set us apart from our competitors and this may produce commercial benefits down the track for us as a brand". R8

While there are clearly different drivers for contractors and developers, the majority of responses were fairly shallow, pragmatic and ultimately regulation and marketdriven - certainly far more pragmatic than those revealed by Peterson and Kadefors (2016) in the Swedish construction industry.

Apart from one respondent, there was no consideration of the broader political and public governance trends which are driving social procurement and of the broader role of construction in building a stronger society. However, the following statement 
is from the respondent who was the exception to this rule. It is worth noting that this person is also the one who innovated to implement the collective impact model described earlier - illustrating the importance of understanding context in the social innovation process.

"I think our position is quite unique because from that early exposure and starting to develop an interest, we became aware of what was happening around the world, particularly in the UK and the concept of the big society. We followed the progress of that initiative. We came to understand that social welfare was an issue that more and more, required creative solutions by governments. Looking at the UK experience, we thought it would only be a matter of time before Australia followed their lead. So we were a bit ahead of the game in looking at the experience in the UK and anticipating that there would be a version of that popping up in Australia".

\section{Conclusion}

The aim of this paper was to address an important gap in the construction management literature around the different types of social procurement used in construction projects, the type of social value being created and the barriers to social procurement which currently exist. Through semi-structured interviews with senior managers responsibility for social procurement in eight major Australian contracting organisations and analysis of their social procurement policies it was found that Type 3 is the most common form of social procurement in the Australian construction industry. The social value created by this type of social procurement is mainly employment and training related and in Australia is mostly targeted at Indigenous groups. This is because Indigenous businesses dominate the emerging third construction sector in Australia due to the preponderance of regulation and support for Indigenous businesses compared to other forms of third sector businesses trading in the construction industry. Every organisation in our sample had engaged an Indigenous business and the penetration of other types of social benefit organisations such as social enterprises and local and minority businesses into the construction industry was limited. In all cases, the main challenges in creating social value using this approach revolve around identifying appropriate and reliable organisations of sufficient scale to work on large construction projects. Social benefit organisations are widely seen as a risk rather than an asset and best confined to low risk, low skilled, non-critical and off-site activities. The barriers facing these organisations in penetrating the industry are also clearly significant constraints on the effectiveness of using this approach to social value creation.

The second most common form of social procurement was Type 1 since $75 \%$ of our sample has purchased social services directly from charities. The type of social value created by this type of social procurement was dictated by the nature of the services which charities provide and include volunteering, mentoring, employment support, community engagement, drug and alcohol services and transportation support etc.. However, in creating social value using this approach, serious challenges remain in working across the differing institutional logics of the construction and charity sectors. There are also challenges in securing collaboration across what is a highly fragmented and competitive third sector, where there exist few incentives to collaborate to create social value. Our results suggest that a collective impact framework might represent an innovative solution to these 
challenges. However, conceptually the collective impact model is still in its infancy and there is a need for empirical evidence to test this hypothesis. In particular, our results indicate that the ability to effectively implement such a model requires specialist expertise which can work across sector boundaries, which is likely to be quite rare.

The third most common form of social procurement was Type 2. Although every respondent had been exposed to them in some way, only $62 \%$ has either used them in their supply chain to generate social value and only $62 \%$ had had them imposed by clients. The type of social value created here was constrained by the capacity of the supply chain to employ and train various disadvantaged groups. Due to the lack of experience in the construction supply chain in employing disadvantaged groups, there is a tendency for social value to be created in the less disadvantaged cohorts that require less knowledge, skills and resources to support. While the existing construction supply chain represents the most powerful force for generating social value, our results indicate that there are significant barriers to the effective use of social clauses in construction projects to create social value in the community. Although we did not delve into the detail design of these clauses (which the literature indicates is a significant determinant of success), these barriers largely revolve around the capacity of industry incumbents to deliver social value and the absence of people who understand these requirements and are able to monitor their implementation in practice.

Type 4 social procurement was the least used by our sample because of the lack of certification and responsible sourcing frameworks which allow socially responsible businesses to be reliably identified. This makes any soft instruments such as codes of supply chain practice largely toothless and ineffective at the moment. The type of social value created here focussed on fair labour and trading practices, good governance and human rights.

Overall, the results indicate that social procurement in construction is largely compliance-driven in response to emerging regulatory and market imperatives.

Social procurement is seen as a risk rather than an opportunity and there appears to be little understanding of broader political trends driving this new variant of traditional procurement or of the important role that construction plays in addressing social disadvantage and inequity. Social procurement in construction is also largely project and place-based, confined to low value and low risk construction activities and constrained by a lack of internal and external capacity. While numerous challenges are identified in enhancing the industry's capacity to leverage its spending for social good, the results suggest that immediate priority should be given to building supply chain capacity to deliver social value and the effective resolution and management of different institutional logics between the business and third sector.

The limitations of this research lie mainly in the relatively small sample size and its focus on Australian major contractors. More research is clearly needed in other organisational and geographical contexts since it is clear that this will significantly influence the types of social procurement employed. Given the lack of construction industry isomorphism around social procurement at the moment, the institutional history and context (both formal and informal) of organisations is likely to significantly influence approaches to social procurement between different firms in the industry. A 
cross-case analysis is therefore likely to generate interesting results and should be pursued in future research. Furthermore, the relationships between national regulatory, economic, political and cultural contexts and the use of social procurement will become clearer when more research is done in other countries. For example, in countries where the state still provides strong welfare support, social procurement is less common, and the social benefit sector is less mature, than in countries with neo-liberal policy settings. Furthermore, now that research is also starting to identify the barriers to social procurement in construction, more focused research is needed on their causes and solutions. Finally, future research could attempt to link the outcomes and lessons of implementing social procurement policies in countries with common social problems and cohorts. For example, given the focus on Indigenous issues in this research it would be useful to undertake research in other countries with significant indigenous populations like South Africa and Canada, where social procurement policies targeting these groups have existed for some time. 


\section{References}

ABS (2002) 1301.0 - Year Book Australia, 2002, Australian Bureau of Statistics, Canberra, Australia

ABS (2015) Labour Force Australia. Cat no 6202.0. Australian Bureau of Statistics, Canberra.

Akotia, J and Parneet, P (2017) An Exploration Of Sustainability Drivers Of Sustainable Regeneration Projects, ARCOM Thirty Third Annual Conference, University of Oxford, UK September 4-6, 360-370

Alcock, P, Butt, C and Macmillan, R (2013) Unity in diversity: What is the future for the third sector? Third Sector Futures Dialogue 2012-2013, Third Sector Research Centre, University of Birmingham

Allen, EJ., 2014. Supply Chain Sustainability School: Phase 2 Final Report 2014. Action Sustainability, CITB. Available at:

http://www.supplychainschool.co.uk/documents/uploads/final\%20report\%20supply\% 20chain\%20sustainability\%20school\%20\%20-\%20december\%202014.pdf

Andayani, W. and Atmini, S., 2012. Corporate Social Responsibility (CSR), Good Corporate Governance (GCG), and Firm Performance. Journal of Modern Accounting and Auditing, ISSN 1548-6583 October 2012, Vol. 8, No. 10, 1484-1495

Arrowsmith, S and Kunzlik, P (2009) Social and Environmental Policies in EC Procurement Law: New Directives and Cambridge University Press, Cambridge, UK

Arvidson, M, Lyon, F, McKay, S and Moro, D (2013) Valuing the social? The nature and controversies of measuring social return on investment (SROI) Voluntary Sector Review, 4 (3), 3-18

Barraket, J, Collyer, N, O'Connor M and Anderson, H (2010) Finding Australia's social enterprise sector: final report, Australian Centre for Philanthropy and nonprofit studies, June Queensland University of Technology, Queensland, Australia.

Barraket, J., Eversole, R. and Luke, B. (2012) Social Enterprise and Regional Development: a pilot study, ACPNS Working Paper 58. The Australian Centre for Philanthropy and Nonprofit Studies, QUT, Brisbane

Barraket, J, Keast, R and Furneaux, C (2016) Social Procurement and New Public Governance. New York: Routledge.

Barraket, J. \& Weissman, J., (2009) Social Procurement and its Implications for Social Enterprise: A literature review. The Australian Centre for Philanthropy and Nonprofit Studies, Queensland University of Technology. Brisbane, Australia. 
Barraket, J and Loosemore, M (2017) Co-creating social value through cross-sector collaboration between social enterprises and the construction industry, Construction Management and Economics, Pages: 1-15 | DOI: 10.1080/01446193.2017.1416152

Bekkers, V. Tummers, L \& Voorberg, W., 2013. From Public Innovation to Social Innovation in the Public Sector: a literature review of relevant drivers and barriers. Rotterdam: Erasmus University Rotterdam.

Blee, G and Pidgeon, C (2014) Implementation of social clauses policy in Northern Ireland, Northern Ireland Assembly, Research and Information Service Briefing Paper, NIAR 925-13, paper 27/15, Belfast, Northern Ireland

Bonwick, M and Daniels, M 2014 Corporate social procurement in Australia: business creating social value, Social Traders, Melbourne, Australia

Bonwick, M. \& Daniels, M. 2013. Corporate Social Procurement in Australia: Business Creating Social Value. The Faculty and Social Traders.

Burke, C and King A (2015) Generating social value through public sector construction procurement: A study of local authorities and SMEs. In: Raiden, A (Ed.) and Aboagye-Nimo, E (Ed.), Proceedings 31st Annual ARCOM Conference, 7-9 September 2015, Lincoln, UK. Association of Researchers in Construction Management, 387-396.

Burkett, I., 2010. Social Procurement in Australia (including A Compendium of Case Studies). Foresters Community Finance. The Centre for Social Impact, University of NSW. Sydney, Australia.

Cabinet Office, 2015. Social Value Act Review - report February 2015. Cabinet Office. London, UK.

CICA (2015) 2015 Construction Industry Outlook, Career Industry Council of Australia, Sydney.

Clandinin, D. J. and Connelly, F. M. (2000). Narrative inquiry: Experience and story in qualitative research. Educational Researcher.-San Francisco: Jossey-Bass, 6, 94118

Commonwealth of Australia (2007) Tackling wicked problems, Australian Government, Canberra, Australia

Daniella Petersen and Anna Kadefors (2016) Social Procurement and Employment Requirements in Construction. In: Chan, P W (Ed.) and Neilson, C J (Ed.), Proceedings 32nd Annual ARCOM Conference, 5-7 September 2016, Manchester UK. Association of Researchers in Construction Management, 9971006. 
Denny-Smith, G and Loosemore, M (2017) "Integrating Indigenous enterprises into the Australian construction industry", Engineering, Construction and Architectural Management, Vol. 24 Issue: 5, pp.788-808

Doherty, B, Haugh, H and Lyon, F (2014) Social Enterprises as Hybrid Organizations: A Review and Research Agenda, linternational Journal of Management Reviews, 16 (4), 417-436.

Doherty, B, Haugh, H and Lyon, F (2014) Social Enterprises as Hybrid Organizations: A Review and Research Agenda, linternational Journal of Management Reviews, Volume 16, Issue 4, pages 417-436,

Edwards, P J and Bowen, P A (2005) Risk management in project organisations, UNSW Press, Sydney, Australia.

Esteves, A M and Barclay, M (2011) Enhancing the benefits of local content: integrating social and economic impact assessment into procurement strategies, Impact Assessment and Project Appraisal, 29:3, 205-215,

European Commission, 2010. Buying Social: A Guide to Taking Account of Social Consideration in Public Procurement, European Commission, Publications Office of the European Union, Luxembourg.

European Union 2014 Directive 2014/24/EU of the European Parliament and of the Council, of $26^{\text {th }}$ February on Public procurement and repealing Directive 2004/18/EC, Official journal of the Eurpoean Union, L94/65 http://eur-lex.europa.eu/legalcontent/EN/TXT/?uri=CELEX:32014L0024, accessed June 2014.

Fady Farag, Peter McDermott and Carrie-Ann Huelin (2016) The Development of an Activity Zone Conceptual Framework to Improve Social Value Implementation in Construction Projects Using Human Activity Systems. In: Chan, P W (Ed.) and Neilson, C J (Ed.), Proceedings 32nd Annual ARCOM Conference, 5-7 September 2016, Manchester UK. Association of Researchers in Construction Management, 975-984.

Farag, FF. \& McDermott, P., 2015. Using soft system methodology to approach social value outcomes in public procurement. Going north for sustainability: Leveraging knowledge and innovation for sustainable construction and development. London South Bank University., 50-59.

Federation of Small Businesses, 2013. Local Procurement - Making the most of small business, one year on. Federation of Small Businesses. London, UK

Flammer, C., 2015. Does Corporate Social Responsibility Lead to Superior Financial Performance? A Regression Discontinuity Approach. Management Science.

Flatau, P. Adams, S and Seivwright, A (2016) The practice, prevalence and funding of outcomes measurement in the community sector: findings from the outcomes measurement in the Western Australian community sector survey, Bankwest 
Foundation Social Impact Series No.5, Centre for Social Impact, University of New South Wales, Swinburne University of Technology University of Western Australia, Australia

Fujiwara D (2013) A general method for valuing non market goods using wellbeing data: three stage wellbeing valuation CEP discussion paper No 1233

Furneaux, C. and Barraket, J., 2014. Purchasing social good(s): a definition and typology of social procurement. Public Money \& Management, 34:4, 265-272,

Glass, J., 2011. Briefing: Responsible sourcing of construction products.

Proceedings of the Institution of Civil Engineers Engineering Sustainability 164 September 2011 Issue ES3 pp. 167-170. doi: 10.1680/ensu.1000011

Glass, J., Achour, N., Parry, T. and Nicholson, I., 2012. Engaging small firms in sustainable supply chains: responsible sourcing practices in the UK construction industry. Int. J. Agile Systems and Management, Vol. 5, No. 1, 29-58.

Guest, Greg (2012). Applied thematic analysis. Thousand Oaks, California: Sage. p. 11.

Halloran, D (2015) A primer on the use of social clauses in Ireland for Community Action Network (CAN) Community Action Network June 2015. Galway, Ireland.

Harlock, J. (2013) Impact measurement practice in the UK third sector: a review of emerging evidence, [Working paper: full academic study]. Third Sector Research Centre, Working Paper 106, Birmingham, UK

Haski-Leventhal, D. (2013). Corporate Volunteering: Connecting people, participation and performance, MGSM, Sydney, Australia

Hennink, M., Hutter, I. \& Bailey, A., 2011. Qualitative Research Methods. SAGE Publications. Los Angeles, USA. ISBN9781412922265

http://www.construction-manager.co.uk/management/opening-our-eyes-supplychain-ethics/: (accessed 4 February 2015)

Himmelan, A T, Berkowitz, B, Christens, B D, Butterfloss, F D, Lee, K S, Bowen L, Minkler, M, WIfe S M and Fransisco V T (2017) Collaborating for Equity and Justice: Moving Beyond Collective Impact, Nonprofit Quarterly January 9, 2017, ttps://nonprofitquarterly.org/2017/01/09/collaborating-equity-justice-moving-beyondcollective-impact/, accessed 10/2/17

Kania, J and Kramer, M (2011) Collective impact, Stanford Innovation Review, Winter 2011, 36-41

Keast,R and Mandell, M (2014) The collaborative push: moving beyond rhetoric and gaining evidence, Journal of Management \& Governance, February 2014, Volume 18 (1), 9-28 
LePage, D (2014) Exploring social procurement, Accelerating Social Impact CCC Ltd, Vancouver, BC, Canada

Loosemore, M (2015) Building the third construction sector through social enterprise, Construction Management and Economics, Volume 33, Issue 9, 724-739

Loosemore M (2016) Social procurement in UK construction projects, International Journal of Project Management, 34 (1) 133-144

Loosemore, M and Denny-Smith, G (2016) Barriers to Indigenous Enterprise in The Australian Construction Industry. In: Chan, P W (Ed.) and Neilson, C J (Ed.), Proceedings 32nd Annual ARCOM Conference, 5-7 September 2016, Manchester UK. Association of Researchers in Construction Management, 629-638.

Loosemore, M and Higgon, D (2015) Social enterprise in the construction industry: Building better communities, Routledge, London.

Loosemore, M and Phua, F (2011) Socially responsible strategy: doing the right thing? Routledge, London.

Loosemore, M and Lim, B (2017) Linking corporate social responsibility and organisational performance in the construction industry, Construction Management and Economics, 35 (3), 95-105

Loosemore, M. and Phua, F. (2011). Corporate social responsibility in the construction industry: doing the right thing? Routledge, London, UK.

Macmillan, R. (2013) Decoupling the state and the third sector? The 'Big Society' as a spontaneous order Third Sector Research Centre, Working Paper, 101. Birmingham, UK

Maier, F and Schober, C S, Simsa, R and Millner, R (2015) SROI as

a Method for Evaluation Research: Understanding Merits and Limitations. voluntas, 26 (5).1805-1830.

Maxwell, J. (1992). Understanding and validity in qualitative research. Harvard Educational Review, 62(3), 279-301.

Meisel, Z F and Karlawish, J (2011) Narrative vs evidence-based medicine - and, not or. Journal of the American Medical Association, 306(18), 2022-2023.

Murray, M, Forbes, D and Mason, S (2011) Considerate constructors scheme: Glenforg Water Treatment works, Engineering Sustainability, 164 (1), 49-57

Nagy Hesse-Biber, S. and Leavy, P., 2011. The practice of qualitative research. Thousand Oaks, SAGE Publications. London, UK. 
Newman, C and Burkett, I 2012 Social procurement in NSW - a guide to achieving social value through public procurement, Social Procurement Action Group, Sydney, Australia

New South Wales Government (2015) NSW Government Policy on Aboriginal Participation in Construction, NSW Procurement Board Secretariat NSW Department of Finance, Services and Innovation, Sydney, Australia

Peterson, D. and Kadefors, A., 2016. Social Procurement and Employment Requirements in Construction. In: PW Chan and CJ Neilson (Eds.) Proceedings of the 32nd Annual ARCOM Conference, 5-7 September 2016, Manchester, UK, Association of Researchers in Construction Management, Vol 2, 997-1006.

Porter, M E. (1985). Competitive Advantage: Creating and Sustaining Superior Performance. New York.: Simon and Schuster.

Porter, M. E. and Kramer, M. R. (2006) Strategy and society, Harvard Business Review, 82: 78-92.

Pritchard, D, NI Ógáin, E and Lumley, T (2013) Making an impact, National Philanthropy Foundation, London, UK

Productivity Commission (2010) Contribution of the not-for-profit sector, Commonwealth of Australia, Canberra

Punch, K., 2014. Introduction to Social Research: Quantitative and Qualitative Approaches. SAGE Publications. London, UK Queensland Government, 2004. Art Built-In Policy. Public Art Agency, Fortitude Valley, Queensland, Australia.

Queensland Government, 2014. The Queensland Government building and construction training policy. Department of Education and Training. Queensland Government, Australia.

References

Reissman, C.K. (2008). Narrative methods for the human sciences. London \& Thousand Oaks: Sage Publications.

Rose L and Bulloch, S (2013) What the public think of the 'Big Society': Mass Observers' views on individual and community capacity for civic engagement, Third Sector Research Centre, Working Paper 95, Birmingham, UK

Seivwright, A, Flatau, P, Adams, S and Stokes, C (2016) The future of outcomes measurement in the community sector in Western Australia, Bankwest foundation, Issue \#6 October 2016, The University of Western Australia, Centre for Social Impact, Perth, Australia

Smith, N J, Merna T and Jobling P (2014) Managing Risk in Construction Projects, 3rd Revised edition, John Wiley and Sons, London 
The National Social Value Taskforce (2018) National TOMs Framework 2018 for social value measurement: Guidance, The National Social Value Taskforce, London, UK

Tilt, C., 2016. Corporate social responsibility research: the importance of context. International Journal of Corporate Social Responsibility 2016 1:2 DOI: 10.1186/s40991-016-0003-7

Toronto City Planning, 2010. Percent for Public Art Program Guidelines. Toronto City Planning, Canada.

Upstill-Goddard, J, Glass, J, Dainty, A R J and Nicholson, I 2012 Integrating responsible sourcing in the construction industry, In: Smith, S.D (Ed.), Proceedings 28th Annual ARCOM Conference, 3-5 September 2012, Edinburgh, UK. Association of Researchers in Construction Management, 1311-19.

Varghese, S (2015) A Paradigm Shift in Human Services Delivery in the United States: A Change in Approach From the Government to the Governance Model, Journal of public policy, https://jpublicpolicy.com/2015/11/29/a-paradigm-shift-inhuman-services-delivery-in-the-united-states-a-change-in-approach-from-thegovernment-to-the-governance-model/, Accessed: 4pm, November $23^{\text {rd }} 2016$.

Villeneuve-Smith, F and Chung, C 2013 Social enterprise UK: The people's business, Social Enterprise UK, London

Villeneuve-Smith, F. and Temple, N., 2015. State of Social Enterprise Survey 2015. Social Enterprise UK.

Whelan, J (2012) Big society and Australia, Centre for Policy Development, May 2012, Melbourne, Australia

Wilson, K., 2016. Investing for social impact in developing countries. Development Co-operation Report 2016 - The Sustainable Development Goals as Business Opportunities. ISSN: 2074-7721 (online) 